\title{
iERBMF
}

\section{Blue Diplomacy of Bangladesh: Connectivity, Capabilities, and Challenges}

\author{
Md. Rezaul Haque \\ Institute of Bangladesh Studies, University of Rajshahi, Bangladesh
}

\begin{abstract}
Bangladesh has become a pilot country of blue economy which is internationally accepted and recognised. As a pilot country of blue economy, Bangladesh has taken some programmes, policy and schemes for the development of her blue economy especially after the final maritime dispute settlement against India in 2014, positive verdict awarded by PCA ( Permanent Court of Arbitration ). Bangladesh is still lagged in its blue diplomacy advancement. Though Bangladesh has some international agreements and negotiations with some international maritime and other international organizations as well as academia like UN, FAO, IMO, UNEP, IORA, WMU, WB, $\mathrm{ADB}$ etc. But, still there is no mentionable improvements in the development of blue diplomacy of Bangladesh for the sake of a prosperous blue economy in Bangladesh. The research paper has a sincere effort to sketch the scenarios like Bangladesh's blue diplomatic connectivity, capabilities and challenges. At the same time, the research paper also has a sanguine endeavour to address some insightful recommendations for the overall further and future development of blue economy of Bangladesh through blue diplomacy.
\end{abstract}

Key Words: Blue Diplomacy, Connectivity, Capabilities, Challenges, Bangladesh

\section{Introduction}

Bangladesh is a maritime country which has a maritime jurisdiction in the Bay of Bengal of total 118,813 sq. km. including 200 NM ( Nautical Miles ) of EEZ and 350 NM ( Nautical Miles ) of Continental Shelf and additionally 200 NM ( Nautical Miles ) of ABNJ( Area Beyond National Jurisdictions). Bangladesh has settled its maritime disputes recently with India and Myanmar in 2012 and 2014 respectively with the positive arbitration and verdict of ITLOS and PCA. After the jurisdiction awards given by two international maritime courts, Bangladesh has adopted some mentionable initiatives, programmes and measures for the establishment and development of her blue economy. Bangladesh has already enacted a legal maritime instrument which has been approved and passed by the parliament of Bangladesh which is now existing as Bangladesh Maritime Zones Act 2019. Before this act, Bangladesh has a historically landmark maritime act which was enacted in 14 February, 1974 named as Territorial Waters and Maritime Zones Act 1974. At the same time, Territorial Waters and Maritime Zones Rules 1977 enacted in 1977.. 


\section{iE}

Actually, the 1974 Maritime Zones Act and 1977 Maritime Zones Rules are the basements of recently passed Maritime Zones Act of 2019. Besides these efforts, Bangladesh is currently working on her blue economy with sectoral vision and pragmatism. Bangladesh has launched a Maritime Affairs Unit in the Ministry of Foreign Affairs. At the same time, Bangladesh has formed a centrally coordination authority named as Blue Economy Cell in 2017 which is a

\section{*Research Fellow, Institute of Bangladesh Studies, University of Rajshahi}

potential wing of Ministry of Power, Energy and Mineral Resources of GoB ( Government of Bangladesh ). About 17 lined departments of blue economy affairs related line ministries. Departments and bodies are under the supervision, monitoring and administration of Blue Economy Cell. This is a notable step of Bangladesh Govt. to enhance the blue economy affair related activities and functioning. Blue diplomacy is a very specialised diplomacy which is about the maritime affairs related diplomacy and a dimension of diplomacy which describes the tools, techniques and strategies for the strengthening of blue economy related economy diplomacy among the littoral and coastal states. Bangladesh has also adopted the concept and is trying to establish her blue diplomacy horizon with the various international maritime organizations and blue economic successful states.

\section{Blue Diplomacy of Bangladesh}

Blue diplomacy is such a diplomacy which is the maritime interest related international negotiations and trade-offs. This diplomacy is not like conventional diplomacy in practice and nature. The blue ocean diplomacy is emergent from the negotiations of the new bilateral and multilateral trade and investment agreements that involved states from all the continents ( Gutu, 2016 ). Blue diplomacy is not as such a traditional economic, cultural or like geopolitical diplomacy. Rather blue diplomacy is a very contemplating and synthetic diplomacy which involves water, economy, politics, international understanding and agreements and so on very professional diplomacy authentically indeed. Blue diplomacy is a mutual interest borne blue economy affairs related multilateral nexus and coexistence.

The history of Bangladesh Blue Diplomacy is since 1974 which then period Bangladesh Govt. enacted a maritime law titled as ' The Territorial and Maritime Zones Act 1974'. This act was enacted for the maritime sovereignty, safety and security of Bangladesh. The act is entitled to 51 clauses. Not only maritime sovereignty but also the act had some instructions on blue economy functioning guidelines as well as blue diplomatic instructions and motivations. Afterwards in 1977 “'Maritime Zones Rules 1977' enacted as an annexure to the original act. The last and updated maritime act has been passed and approved by GoB ( Government of Bangladesh ) recently which is titled as 'Bangladesh Maritime Zones Act 2019'. 
Bangladesh is always aware and pro-active in blue diplomacy initiative. Bangladesh has some notable international and multinational organizations including UN to conduct her blue diplomacy functions properly and smoothly. Bangladesh has signed some MoUs ( Memorandum of Undestandings ) with different successful and prosperous blue economy countries categorically as bilateral as well as multilateral. Bangladesh has signed MoU with China and India to invest in multidimensional blue economy sectors of Bangladesh. Bangladesh welcomes the FDI ( Foreign Direct Investment ) flow in Bangladesh's blue economy. Bangladesh is a signatory member of China's great RBI ( Road and Belt Initiative ) project. Bangladesh is also a member of IORA ( Indian Ocean Rim Association ) which is also a giant maritime organization based on Indian Ocean related and associated countries.

\section{Blue Diplomacy Connectivity of Bangladesh}

Blue diplomacy connectivity is a major and indispensable agenda in terms of fostering blue growth of any blue economy state. As blue diplomacy is not like conventional diplomatic orientations, so blue diplomacy requires special caring and seriousness. To enhance the blue economy functioning and to build blue economy successful with sustainability in real terms, every littoral state should extend the horizon of blue diplomacy connectivity. Bangladesh has also taken some steps to foster her blue diplomacy and blue diplomacy related connectivity. Bangladesh has already gained the international memberships of IMO, ITLOS, PCA, IORA, BIMSTEC etc. At the same time, Bangladesh is busy through her diplomatic missions and embassies abroad to achieve the memberships of another international maritime and maritimeassociated organisations. Bangladesh has already signed MoU ( Memorandum of Understanding ) with blue economy successful countries like India, China, Malaysia, Thailand, USA, Australia, Vietnam etc. Ministry of Foreign Affairs of GoB has a specialised wing named as Maritime Affairs Unit ( MAU ) which is seriously a designated wing of MoFA ( Ministry of Foreign Affairs ) works for blue diplomatic connectivity overall. Besides MAU of MoFA, Ministry of Shipping, Ministry of Fisheries and Livestock, Ministry of Commerce, Ministry of Civil Aviation and Tourism etc are also proactive for blue economy related economic diplomacy enhancement for the overall development of blue economy of Bangladesh.

\section{Blue Diplomacy Capabilities of Bangladesh}

Bangladesh has huge potentials in blue diplomacy. Bangladesh has already proved her competence in blue diplomacy with the engagement of various bilateral, multilateral partnerships through MoUs and another tools of agreements among blue economy successful countries and organisations. The international memberships of various maritime organizations is another sign of blue diplomacy capability of Bangladesh. Bangladesh fist enacted a maritime act just after her independence in 14 March, 1974. Then President and Father of the Nation of Bangladesh 


\section{iEREMF}

Bangabandhu Sheikh Mujibur Rahman took the landmark initiative to enact a law named as The Territorial Waters and Maritime Zones Act 1974. The act has 9 main clauses or conventions and 42 sub-clauses or sub-conventions. That act was the historically first maritime act of Bangladesh. And later on, the UN Convention on maritime affairs which is called as UNCLOS-III and which was enacted in 1982 named as United Nations Convention on the Law of the Sea ( UNCLOS )1982. Bangladesh has ratified the convention also. Bangladesh needed to amend her first with the contemporary orientations on maritime affairs. Recently, Bangladesh has passed another law in the parliament named as The Bangladesh Maritime Zones Act-2019 which was enacted on 5 December,2018. The act has a total of 156 conventions, main 137 conventions including 19 annexed sub-conventions which has become a contemporary, smart, visionary and sustainable maritime act for such a country like Bangladesh. Bangladesh has established blue economy connectivity with inter-coastal and blue technology smart countries like Norway, Australia, Japan etc. Bangladesh seeks technical assistance from blue technology successful countries like China. Recently, Bangladesh has signed a MoU for MSS ( Multi-client Seismic Survey) with USA based company to explore mineral resources like oil and gas in the Bay of Bengal. These all issues show that Bangladesh is capable of doing better in future in blue diplomacy.

\section{Tools and Roles for Blue Engagement of Blue Diplomacy}

\begin{tabular}{|c|c|c|c|}
\hline Tools & National/Sub-National & Basin & Global \\
\hline Institutional and Legal & $\begin{array}{l}\text { Strengthen domestic } \\
\text { and national water } \\
\text { institutions } * *\end{array}$ & $\begin{array}{l}\text { Support new and } \\
\text { strengthen existing } \\
\text { basin agreements } * *\end{array}$ & $\begin{array}{l}\text { Support principles and } \\
\text { codification of } \\
\text { international law* }\end{array}$ \\
\hline Capacity Building & $\begin{array}{l}\text { Improve national } \\
\text { water use practices } \\
\text { and institutions } * * *\end{array}$ & $\begin{array}{l}\text { Develop capacity } \\
\text { through training ) in } \\
\text { water and diplomatic } \\
\text { communities } * *\end{array}$ & $\begin{array}{l}\text { Diffuse knowledge on } \\
\text { appropriate } \\
\text { stakeholder } \\
\text { processes } * *\end{array}$ \\
\hline Financial & $\begin{array}{l}\text { Fund cross-sectoral } \\
\text { capacity building } * * *\end{array}$ & $\begin{array}{lr}\text { Fund intra-basin } \\
\text { confidence building } \\
\text { processes ( e.g., joint } \\
\text { datar collection, } \\
\text { monitoring systems } \\
)_{* *}\end{array}$ & $\begin{array}{l}\text { Fund global early } \\
\text { warning and crisis } \\
\text { response } \\
\text { mechanisms*** }\end{array}$ \\
\hline Political coordination & $\begin{array}{l}\text { Ensure cross-sectoral } \\
\text { coherence ( e.g., } \\
\text { climate adaptation and } \\
\text { conflict resilience })^{* *}\end{array}$ & $\begin{array}{ll}\text { Offer fact finding } \\
\text { support and engage } \\
\text { preventively* }\end{array}$ & $\begin{array}{l}\text { Overcome } \\
\text { international political } \\
\text { inertia/create } \\
\text { institutional } \\
\text { platform** }\end{array}$ \\
\hline
\end{tabular}

Source: Adapted from Pohl ( 2014 )

Note: * Tasks for foreign policy makers and diplomats 
** Shared Tasks.

*** Tasks for Development community

\section{Global Blue Diplomacy Framework}

A successful and effective blue diplomacy requires multidimensional coordinated settings. A successful blue diplomacy requires a grand nexus among blue economy policy, blue economy activities, blue strategic initiatives, blue economy mechanism etc. Bangladesh requires a handsome blue diplomacy framework or roadmap for her sustainable advancements of blue economy.

Before presenting a proposed blue diplomacy framework of Bangladesh, we have to look at the global blue diplomacy framework which is should be realised as well. The international blue diplomacy framework is given as accordingly.

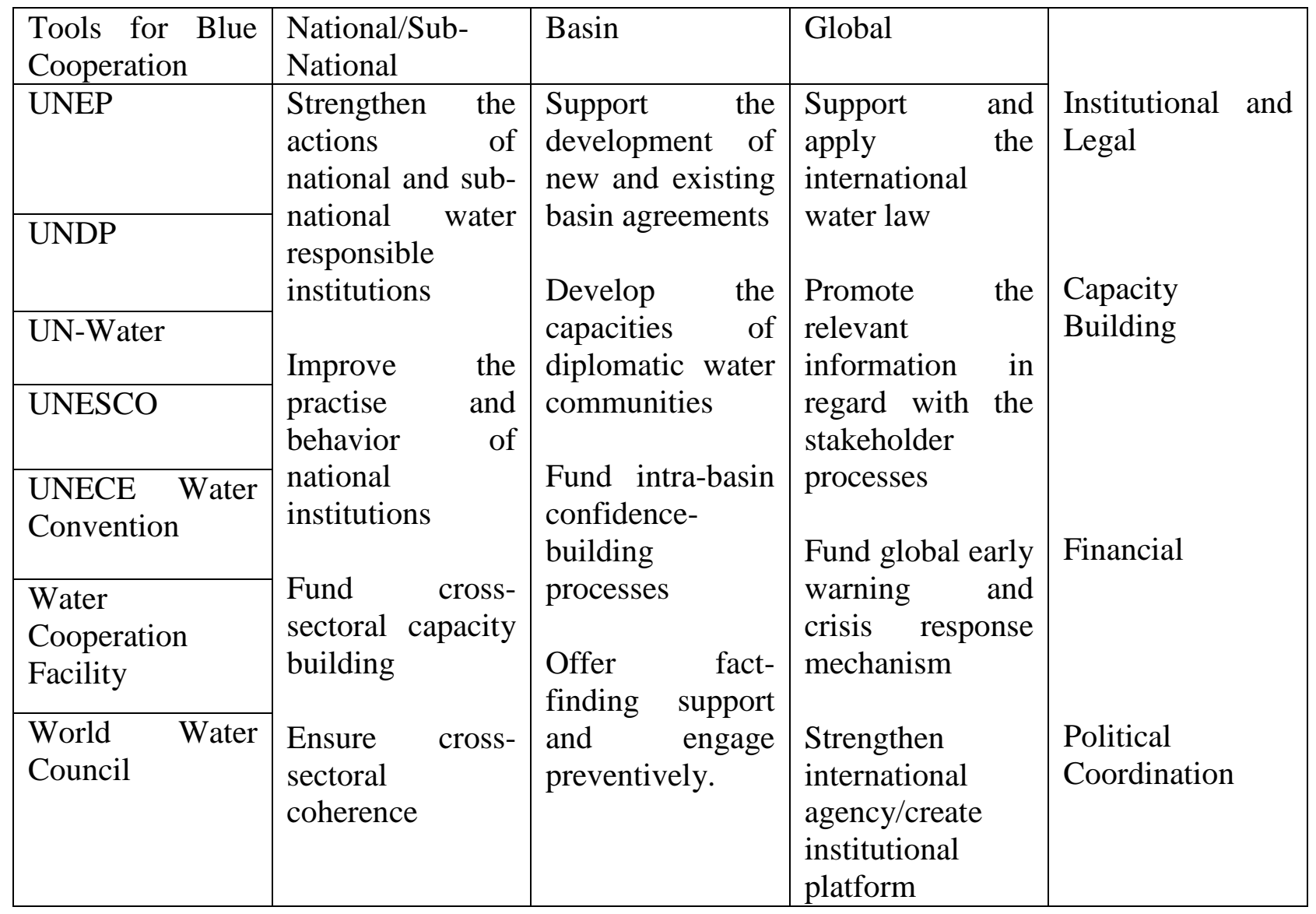

Table: Global Framework of Blue Diplomacy 
Source: Adapted after Pohl, Benjamin, 2014

The abovementioned table shows the international framework of blue diplomacy which has been cited from Pohl and Benjamin ( 2014 ). The framework shows very vividly the components and characteristics of blue diplomacy globally such as tools of blue diplomacy, national and subnational measures for blue diplomacy, marine basin strength and doings and finally the global initiatives and approach.

\section{Proposed Blue Diplomacy Framework of Bangladesh}

Bangladesh's blue diplomacy framework should be formed according to the structure and mechanism of global blue diplomacy because blue diplomacy is multilateral and absolutely international. Bangladesh blue diplomacy framework should be formed in such a manner that must be based on Bay of Bengal settings also because Bangladesh blue economy based on Bay of Bengal and it has six stakeholder or shared coastal countries like Bangladesh, India, Sri Lanka, Myanmar, Indonesia and Thailand. And there are also some dependent countries. So, Bangladesh blue diplomacy framework should be in such a fashion which covers all the settings with the associated countries and must be a sustainable one. The study tries to figure out a proposed blue diplomacy framework for Bangladesh considering the sustainability of the scenario, 


\section{iEREMF}

Bangladesh's blue diplomacy framework should be formed according to the global as well as regional setting so that all issues can be met altogether and blue diplomacy of Bangladesh can get a feasible as well as durable in nature. The proposed framework is given below.

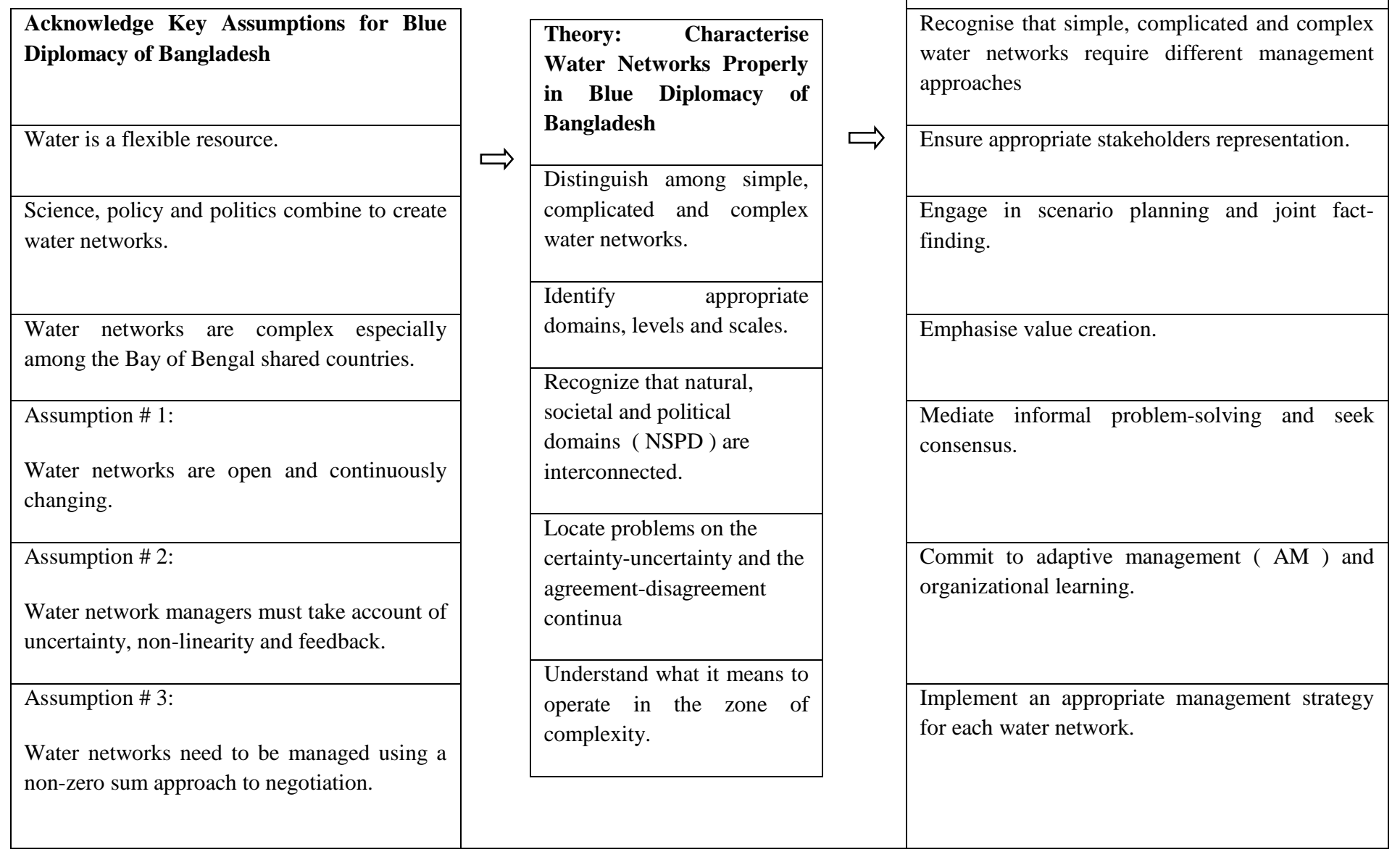

Table; Table: Proposed Blue Diplomacy Framework of Bangladesh

Source: Islam and Repella ( $2015: 2$ ) and Developed by Author 


\section{Blue Diplomacy Challenges of Bangladesh}

Bangladesh is still a novice country in terms of her blue diplomatic connectivity and capabilities. There are lots of challenges and constraints in the way of blue diplomacy of Bangladesh. The challenges and constraints are multidimensional as well as multilateral. The challenges are stated below.

1) Diplomatic failure of diplomatic missions abroad of Bangladesh.

2) Lack of blue diplomacy understanding of blue economy as well as national policy makers of Bangladesh.

3) Absence of blue diplomacy roadmap of Bangladesh

4) Bargaining ineligibility in the international blue economy platforms of Bangladesh

5) Non-implementation of MoUs between Bangladesh and other coastal countries including international maritime organisations.

6) Lack of National Blue Economy Policy

7) Lack of blue diplomacy knowledge, training and understanding of diplomats and respective govt. authorities.

8) Lack of academic blue diplomacy research in Bangladesh.

9) Lack of geopolitical understanding among Bay of Bengal shared coastal countries.

10) Climate change induced impacts and degraded ocean environment in the Bay of Bengal.

11) Lack of coordination and cooperation in the Bay of Bengal shared countries like EU states shared seas and blue economy related visionary coordinated strategy and understanding.

12) Increased competition, hegemony and distrust between Bangladesh and Bay of Bengal shared countries.

13) Absence of blue diplomacy wing in the diplomatic missions of Bangladesh.

14) Mutual distrust and imbalance of power among BIMSTEC countries

15) Presence of multiple stakeholders in the Bay of Bengal and their conflicts.

16) Wastage and exploitation of marine resources

17) Lack of adequate investment in blue economy sectors

18) Absence of adequate FDI flow in blue economy sectors of Bangladesh

19) Absence of smart blue technology in Bangladesh etc. 


\section{iERBMF}

The challenges abovementioned are so far the constraints and challenges of blue diplomacy of Bangladesh and needed to be removed for the foster and sustainable growth of blue diplomacy of Bangladesh.

\section{Recommendations}

Blue diplomacy is an internationally indispensable instrument for the development of blue economy for any coastal or littoral state. Especially SIDS ( Small Island Developing States ) and coastal developing countries should strengthen their blue diplomatic horizon and connectivity for their desirable blue economy harness and enhancement so that they can take their maximum benefit from their seas and oceans. Bangladesh is not exception in this approach. There are some recommendations below to foster the growth of blue diplomacy of Bangladesh.

a) Strengthen of Bangladeshi missions abroad to bargain with the international communities for the economic as well as sustainable development interest of blue economy of Bangladesh.

b) Arrangement of national as well as international training of blue economy policy makers of Bangladesh.

c) Launch of a sustainable and visionary blue diplomacy roadmap.

d) Proper measures to strengthen the bargaining eligibility of Bangladeshi representatives in the international blue economy platforms.

e) Effective steps to implement the MoUs between Bangladesh and other coastal countries as well as with other international organisations.

f) Launch of a sustainable, pragmatic and effective National Blue Economy Policy.

g) Adequate initiatives should be taken to conduct blue diplomacy research in all academic grounds especially at university levels.

h) Strengthening geo-political understanding among Bay of Bengal shared countries.

i) Effective measures to mitigate the climate change impacts on blue economy and ocean environment.

j) Strengthening cooperation and coordination among Bay of Bengal stakeholder countries to excel their blue diplomatic interests.

k) Continuation of dialogues and steps to remove distrust, hegemony and unexpected excess competition and rivalry among Bay of Bengal shared countries including Bangladesh.

1) Removal of maritime piracy and maritime smuggling in the Bay of Bengal of Bangladesh.

These are so far some suggestions and recommendations for the development blue diplomacy of Bangladesh and overall for the development of blue economy of Bangladesh 


\section{iERBMF}

m) Adequate investment in the blue economy sectors of Bangladesh

n) More attention drawing effort to attract foreign investors.

o) Maximum mitigation of wastage and exploitation of marine resources of Bay of Bengal of Bangladesh

p) Adequate govt. budgeting for blue diplomacy communications and enhancement etc. The abovementioned recommendations are so far the suggestions that can contribute towards the development and enhancement for the blue diplomacy connectivity and capabilities of Bangladesh. Especially, Ministry of Foreign Affairs of Bangladesh. altogether with the Bangladeshi foreign diplomatic missions abroad can play the premier role to strengthen the blue diplomacy horizon of Bangladesh.

\section{Conclusion}

Blue diplomacy refers many issues overall. Blue diplomacy is very much important as well as significant for the proper functioning and mechanism of blue economy of any coastal country. Bangladesh needs such a strong and durable blue diplomacy by which Bangladesh can extend her blue economy activities systemically and sustainably. So that Bangladesh can achieve a sustainable and fostered blue growth landmark for her blue economy. To achieve the goals and objectives, Bangladesh diplomatic missions have to play the lion portion role to build a concrete blue diplomacy of Bangladesh. Especially, in the international platforms, Bangladesh has to raise the maximum voice to get the equity and justice. At the same time, Bangladesh has to maintain a sensible and sustainable connectivity with the neighbouring Bay of Bengal littoral states. And this is how, Bangladesh can be an icon and model in the blue diplomacy discussion and platforms in the world.

\section{References}

Bangladesh Territorial and Maritime Zones Act 1974

Bangladesh Maritime Zones Act 2019

Conca, K. 2012, ' Decoupling Water and Violent Conflict' Issues in Science and Technology, vol. 29 , no. 1, pp. 39-49.

Ioana GUTU, 2016. "The Transatlantic Blue Diplomacy," CES Working Papers, Centre for European Studies, Alexandru Ioan Cuza University, vol. 8(4), pages 666-680.

Islam, Shafiqul and Repella, Amanda C., 2015 'Water Diplomacy: A Negotiated Approach to Manage Complex Water Problems' Journal of Contemporary Water Research and Education, Issue. 155, pp. 1-10. 
$3^{\text {rd }}$ International Conference on Research in BUSINESS, MANAGEMENT and FINANCE

\section{iERBMF}

Pohl, B. 2014 , 'The Rise of Hydro-Diplomacy Strengthening Foreign Policy for Transboundary Waters' Adelphi Research gemelnnotzalge GmbH and German Federal Foreign Office, 1 July, 2014.

Territorial Water and Maritime Zones Rules 1977

United Nations Convention on the Law of the Sea ( UNCLOS )-III, 1982

Wolf, A. T. 2007, 'Shared Waters: Conflict and Cooperation', Annual Review of Environment and Resources, vol. 32, pp. 241-269. 